\title{
OPTIMASI PERENCANAAN PRODUKSI PENJUALAN HIJAB MENGGUNAKAN METODE FUZZY LINIER PROGRAMMING
}

\author{
Indriana Putri Solehah ${ }^{1}$, Laila Fitriana ${ }^{2}$ \\ ${ }^{1,2}$ Pendidikan Matematika UNS Surakarta
}

\begin{abstract}
Currently, hijab is very interesting thing in the community. Seeing from the many uses of hijab by Muslim women, the production of hijab is adjusted to those needs. The problem faced by hijab producers is how much hijab will be made with all constraints and limitations. One method that can be used for optimization of production planning is Fuzzy Linear Program and LINDO Program. Fuzzy Linear Program is a linear program method that is applied in a fuzzy environment, while the LINDO program is a program designed to solve linear cases of programming which use certain formats to be processed by LINDO program. From the above problems, the authors solve this hijab production problem using Fuzzy Linear Programming to determine the right number for each model with maximum profit.
\end{abstract}

Keywords:Hijab, Fuzzy Linear Programming, Simplex Method, LINDO.

\section{PENDAHULUAN}

Sebagian besar persoalan manajemen adalah berkenaan dengan penggunaan sumber daya secara efisien atau pengalokasian sumber-sumber yang terbatas untuk mencapai tujuan yang diinginkan sehingga terdapat kendala-kendala yang membatasi produksi suatu perusahaan.Kendala-kendala tersebut dapat berupa kapasitas mesin, ketersediaan waktu kerja, dan ketersediaan bahan baku.Salah satu faktor yang mempengaruhi keberhasilan suatu perusahaan adalah perencanaan produksi yang baik. Suatu perencanaan produksi dikatakan baik jika perencanaan tersebut dapat memenuhi permintaan pasar dengan menggunakan biaya yang minimum untuk mendapatkan hasil yang optimal.

Oleh karena itu penulis tertarik untuk melakukan penelitian mengenai produksi hijab di Solo.Permintaan pasar yang semakin meningkat membuat pemilik usaha hijab mengambil keputusan untuk menaikkan jumlah produksinya, namun terkendala dalam menentukan jumlah bahan dan tenaga kerja yang akan mengerjakannya.Oleh karena itu diperlukan perhitungan yang cermat untuk mengoptimalkan biaya produksi dan menentukan jumlah yang tepat dengan hasil produksi yang lebih baik.

Penelitian serupa juga telah dilakukan oleh Martini (2017) yang menyatakan bahwa permasalahan tentang produksi merupakan masalah yang sulit untuk mengetahui untung ruginya, sehingga diperlukan perhitungan yang cermat dengan metode yang tepat. Maka dalam penelitian ini, akan dibahas tentang pembentukan model persamaan Fuzzy Linear Programming dengan studi kasus produksi hijab rumahan.Effisiensi produksi dan pengoptimalan kinerja dalam suatu perusahanan dapat dicapai dengan menggunakan model optimasi. Model optimasi dapat dituliskan dalam sebuah fungsi persamaan dan 
pertidaksamaan yang dikenal dengan nama Program Linier. Program Linier dapat dikombinasikan dengan nilai fuzzy untuk menyesuaikan model permasalahan produksi yang sangat bergantung pada permintaan pasar yang berubah-ubah. Pemodelan ini dikenal dengan nama Fuzzy Linear Programming. Maka perumusan masalah ini adalah bagaimana prosedur dari Fuzzy Linear Programming dan program LINDO untuk optimasi perencanaan produksi sedangkan tujuan penulisan ini adalah menjelaskan prosedur dari Fuzzy Linear Programming dan program LINDO untuk mencari optimasi perencanaan produksi.

\section{METODE PENELITIAN}

Pada permasalahan ini akan membahas mengenai penggunaan fuzzy linier programming untuk menyelesaikan masalah optimasi. Akan dibahas mengenai penggunaan Metode Simpleks yang digunakan dalam perhitungan baik untuk menentukan variabel dasar dalam non-fuzzy maupun untuk Fuzzy Linear Programming dan akan dibahas prosedur dalam memasukkan data ke dalam program LINDO.

\section{A. Pemrograman Linier Metode Simpleks}

Program linier merupakan suatu teknik optimasi untuk menemukan suatu penyelesaian dari sebuah fungsi tujuan yang berbentuk linier terhadap sumber-sumber terbatas yang berbentuk linier secara optimal.Dalam program linier, batasan-batasan yang terdapat dalam masalah program linier diterjemahkan terlebih dahulu ke dalam bentuk perumusan matematika.Model matematika yang digunakan untuk mengemukakan suatu permasalahan program linier adalah sebagai berikut.

Fungsi tujuan:

Memaksimumkan/Meminumkan $\mathrm{Z}=\sum_{j=1}^{n} c_{j} . x_{j}$

Terhadap batasan-batasan:

$a_{11} x_{1}+a_{12} x_{2}+a_{13} x_{3}+\ldots \ldots \ldots \ldots+a_{1 n} x_{n}(\leq,=, \geq) b_{1}$

$a_{m 1} x_{1}+a_{m 2} x_{2}+a_{m 3} x_{3}+\ldots \ldots \ldots \ldots+a_{m n} x_{n}(\leq,=, \geq) b_{m}$

dan $\forall x_{j} \geq 0$

(Siswanto, 2007: 30)

Pemrograman Linear mengidentifikasikan satu pemecahan dasar awal yang dibuat secara sistematis menjadi pemecahan dasar lainnya dan memperbaiki nilai fungsi tujuan. Model Linear Programming memiliki tiga komponen dasar (Taha, 2007):

1. Variabel keputusan yang akan ditentukan 
2. Tujuan (goal) yang perlu dioptimalkan (memaksimalkan atau meminimalkan)

3. Kendala yang solusinya harus memuaskan

Tabel 1. Tabel Simpleks

\begin{tabular}{|c|c|c|c|c|c|c|c|c|c|c|c|c|}
\hline Basic & VB & $\mathbf{Z}$ & $\mathbf{x}_{1}$ & $\mathbf{x}_{2}$ & $\cdots$ & $\mathbf{x}_{\mathbf{n}}$ & $\mathbf{x}_{\mathbf{n}+\mathbf{1}}$ & $\mathbf{x}_{\mathrm{n}+2}$ & ... & $\mathbf{x}_{\mathbf{n}+\mathbf{m}}$ & NK & Rasio \\
\hline & $\mathbf{Z}$ & 1 & $-c_{1}$ & $-c_{2}$ & $\ldots$ & $-c_{n}$ & 0 & 0 & $\ldots$ & 0 & 0 & \\
\hline & $x_{n+1}$ & 0 & $a_{11}$ & $\mathrm{a}_{12}$ & $\ldots$ & $a_{1 n}$ & 1 & 0 & $\ldots$ & 0 & $\mathrm{~b}_{1}$ & \\
\hline & $x_{n+2}$ & 0 & $a_{21}$ & $a_{22}$ & $\ldots$ & $a_{2 n}$ & 0 & 1 & $\ldots$ & 0 & $\mathrm{~b}_{2}$ & \\
\hline & • & · & $\cdot$ & $\cdot$ & $\cdots$ & $\cdot$ & . & . & $\cdots$ & . & · & \\
\hline & • & $\cdot$ & $\cdot$ & · & & $\cdot$ & $\cdot$ & $\cdot$ & & $\cdot$ & . & \\
\hline & . & . & . & . & &. &. &. & & . &. & \\
\hline & $\mathbf{x}_{\mathbf{n}+\mathbf{m}}$ & 0 & $a_{\mathrm{m} 1}$ & $a_{\mathrm{m} 2}$ & $\ldots$ & $\mathrm{a}_{\mathrm{mn}}$ & 0 & 0 & & 1 & $\mathrm{~b}_{\mathrm{m}}$ & \\
\hline
\end{tabular}

Fungsi tujuan dapat berbentuk maksimisasi atau minimisasi, dan kendala linear dapat berbentuk lebih kecil sama dengan $(\leq)$ atau lebih besar sama dengan $(\geq)$. Semua kendala linear tersebut harus ditransformasikan dalam bentuk persamaan, dan menambahkan variabel slack, variabel surplus dan variabel buatan pada ruas kiri kendala linear.

\section{B. Fuzzy Linear Programming}

Penyelesaian dengan program linier fuzzyadalah pencarian suatu nilai $Z$ yang merupakan fungsi obyektif yang akan dioptimasikan sedemikian rupasehingga tunduk pada batasan-batasan yang dimodelkan dengan menggunakanhimpunan fuzzy(Kusumadewi, 2004: 376).

Asumsi bahwa keputusan program linier akan dibuat pada lingkungan fuzzy, akan sedikit berubah, yaitu:

1. Bentuk imperative pada fungsi obyektif tidak lagi benar-benar "maksimum" atau "minimum", karena adanya beberapa hal yang perlu mendapat pertimbangan dalam suatu sistem.

2. Tanda $\leq$ (pada batasan) pada kasus maksimasi dan tanda $\geq$ (pada batasan) dalam kasus minimasi tidak lagi bermakna crisp secara matematis. Hal ini juga disebabkan karena adanya beberapa yang perlu dipertimbangkan dalam sistem yang mengakibatkan batasan tidak dapat didekati secara tegas.

Selanjutnya dalam penulisan ini hanya akan dibahas untuk persoalan maksimasi. Model matematika umtuk persoalan maksimasi adalah sebagai berikut:

Tentukan $\mathrm{x}$ sedemikian hingga:

$c^{T} x \gtrsim z$

$$
\begin{aligned}
A x & \lesssim b \\
x & \geq 0
\end{aligned}
$$


dimana $\mathbf{x}=\left(\mathrm{x}_{1}, \mathrm{x}_{2}, \ldots, \mathrm{x}_{\mathrm{n}}\right)$ adalah vektor variabel, $\mathbf{c}=\left(\mathrm{c}_{1}, \mathrm{c}_{2}, \ldots, \mathrm{c}_{\mathrm{n}}\right)$ adalah vektorbiaya, $A=\left(a_{i j}\right)$ adalah matriks kendala berukuran $m \times n$, dan $\mathbf{b}=\left(\mathrm{b}_{1}, \mathrm{~b}_{2}, \ldots, \mathrm{b}_{\mathrm{n}}\right)$ adalah vektor $\mathbf{x} \epsilon \mathbb{R}^{\mathbf{n}}$ yang memenuhi semua kendala

Dengan tanda' $\lesssim$ 'merupakan bentuk fuzzy dari' $\leq$ 'yang menginterpretasikan pada dasarnya kurang dari atau sama dengan. Demikian pula, tanda ' $~ \gtrsim$ ' merupakan bentuk fuzzy dari ' $\geq$ ' yang menginterpresentasikan "pada dasarnya kurang dari atau sama dengan"

\section{LINDO}

LINDO kependekan dari Linier Interactive Discrete Optimizer, adalah sebuah program yang dirancang untuk menyelesaikan kasus-kasus pemrograman linier yang menggunakan format tertentu agar bisa diolah oleh program LINDO.Jadi berbeda dengan program-program lain yang menggunakan desain menu driven system dimana pemakai (user) tinggal memasukkan data sesuai permintaan program secara bertahap.

LINDO bisanya digunakan oleh perusahaan untuk memaksimalkan keuntungan dan meminimumkan biaya. LINDO juga dapat digunakan dalam pengambilan keputusan perencanaan produksi, transportasi, pengaturan modal, penjadwalan, dan lain-lain(Amindo, 2006).

Menurut Amindo (2006), tahapan dalam pengaplikasian LINDO meliputi

1. Merumuskan masalah dalam program linier

2. Menuliskan dalam persamaan matematik

3. Memasukkan rumus ke dalam LINDO

4. Interpretasi LINDO

Program LINDO menghendaki masukan model matematika dengan format yang standar.Masukan model matematika akan diolah sehingga dapat menghasilkan keluaran.Hasil keluaran dari program LINDO dapat langsung diketahui sisi sensitivitasnya.Analisis sensitivitas program LINDO berisi mengenai nilai interval yang dimilki sasaran kendala (Siswanto, 2007).

\section{HASIL DAN PEMBAHASAN}

Penelitian ini dilakukan kepada seorang produsenbusana muslim di Solo. Usaha hijab ini telah berdiri sejak 2016 dan terus berkembang sampai sekarang.Dengan menggunakan marketing penjualan secara online, reseller dan offline, membuat usaha ini semakin berkembang dan meningkatnya produksi pembuatan hijab.Dari usahanya tersebut ia mempunyai 4 orang pegawai diantaranya 2 pegawai sebagai penjahit dan 2 
pegawai sebagai operator.Produk yang baru bisa dibuat adalah hijab dengan berbagai model dan disesuaikan dengan trend busana muslim di masyarakat.

Penelitian dilakukan pada sebuah usaha mandiri yang memproduksi hijab atau kerudung. Banyak model yang dibuat tetapi dalam penelitian ini hanya membahas 2 model yaitu hijab kain (lembaran) dan hijab instan (siap pakai).Untuk setiap model dikerjakan oleh seorang pekerja. Bahan yang digunakan untuk hijab kain dan hijab instan adalah bahan woolpeach dengan lebar bahan $1,5 \mathrm{~m}$ dan harga Rp. 23,500/m. Jenis bahan ini banyak diminati terutama oleh kalangan remaja dan dewasa. Model yang dibahas pada penelitian ini adalah:

\section{Hijab Kain}

a. Model $1\left(\mathrm{x}_{1}\right)$ adalah hijab segiempat dengan tepi neci atau dijahit kecil. Untuk model ini memerlukan bahan $2 \mathrm{~m}$ dan waktu pembuatan 5 menit. Harga yang dijual adalah Rp. 50.000 .

b. Model $2\left(\mathrm{x}_{2}\right)$ adalah hijab pashmina dengan tepi dijahit.Untuk model ini memerlukan bahan $2 \mathrm{~m}$ dan waktu pembuatan 10 menit.Harga yang dijual adalah Rp. 60.000 .

2. Hijab Instan

c. Model $1\left(\mathrm{x}_{1}\right)$ adalah hijab instan pasmina dengan berbagai variasi hiasan. Untuk model ini memerlukan bahan 2,5m dan waktu pembuatan 15 menit. Harga yang dijual adalah Rp. 90.000.

d. Model $2\left(\mathrm{x}_{2}\right)$ adalah hijab instan (bergo) dengan berbagai variasi hiasan. Untuk model ini memerlukan bahan 2,2m dan waktu pembuatan 10 menit. Harga yang dijual adalah Rp. 75.000 .

Untuk menyelesaikan pembuatan hijab tersebut ada batasan yang perlu diketahui bahwa dalam sehari hanya tersedia bahan 100m untuk hijab kain dan 100m untuk hijab instan dan waktu pembuatan adalah 8 jam (480 menit). Dari analisa di atas ingin diperoleh keuntungan yang maksimum dengan menghasilkan hijab yang tepat untuk tiaptiap model dengan batasan yang ada. Karena ada peningkatan permintaan hijab, maka masing-masing pekerja boleh melakukan lembur dengan penambahan waktu 1 jam (60 menit) sedangkan bahan akan ditambah untuk tiap jenisnya sebanyak $15 \mathrm{~m}$ saja mengingat waktu lembur hanya disediakan tidak lebih dari 1 jam.

\section{A. Perhitungan Non-Fuzzy untuk Hijab Kain dan Pasmina}


Berdasarkan analisa Permasalahan pertama dapat disederhanakan dalam bentuk matematis untuk persoalan maksimilisasi

Maksimumkan $\mathrm{z}=50000 \mathrm{x}_{1}+60000 \mathrm{x}_{2}$

Kendala $\quad 2 x_{1}+2 x_{2} \quad \leq 100$

$$
\begin{aligned}
& 5 \mathrm{x}_{1}+10 \mathrm{x}_{2} \leq 480 \\
& \mathrm{x}_{1}, \mathrm{x}_{2} \geq 0
\end{aligned}
$$

Dengan menerapkan langkah-langkah aturan dalam metode simpleks diperoleh

\begin{tabular}{|c|c|c|c|c|c|c|c|c|}
\hline Basic & VB & $\mathbf{Z}$ & $\mathbf{x}_{1}$ & $\mathbf{x}_{2}$ & $\mathbf{S}_{1}$ & $\mathbf{s}_{2}$ & NK & RASIO \\
\hline ITERASI (0) & $\mathrm{Z}$ & 1 & $\begin{array}{c}- \\
50000\end{array}$ & $\begin{array}{c}- \\
60000\end{array}$ & 0 & 0 & 0 & - \\
\hline $\mathbf{E V}=\mathrm{x}_{2}$ & $\mathrm{~s}_{1}$ & 0 & 2 & 2 & 1 & 0 & 100 & 50 \\
\hline \multirow[t]{2}{*}{$\mathbf{L V}=\mathbf{s}_{\mathbf{2}}$} & $\mathrm{s}_{2}$ & 0 & 5 & 10 & 0 & 1 & 480 & 48 \\
\hline & VB & $\mathbf{Z}$ & $\mathbf{x}_{1}$ & $\mathbf{x}_{2}$ & $s_{1}$ & $\mathbf{s}_{2}$ & NK & RASIO \\
\hline ITERASI (1) & $\mathrm{Z}$ & 1 & $\begin{array}{c}- \\
20000\end{array}$ & 0 & 0 & 6000 & 2880000 & - \\
\hline$E V=x_{1}$ & $\mathrm{~s}_{1}$ & 0 & 1 & 0 & 1 & $-0,2$ & 4 & 4 \\
\hline \multirow[t]{2}{*}{$\mathbf{L V}=\mathbf{s}_{\mathbf{1}}$} & $\mathrm{x}_{2}$ & 0 & 0,5 & 1 & 0 & 0,1 & 48 & 96 \\
\hline & VB & $\mathbf{Z}$ & $\mathbf{x}_{1}$ & $\mathbf{x}_{2}$ & $\mathbf{s}_{1}$ & $\mathbf{s}_{2}$ & NK & RASIO \\
\hline ITERASI (2) & $\mathrm{Z}$ & 1 & 0 & 0 & 20000 & 2000 & 2.960 .000 & \\
\hline \multirow[t]{2}{*}{ OPTIMAL } & $\mathrm{x}_{1}$ & 0 & 1 & 0 & 1 & $-0,2$ & 4 & \\
\hline & $x_{2}$ & 0 & 0 & 1 & $-0,5$ & 0,2 & 46 & \\
\hline
\end{tabular}

Tabel 2. Pemecahan Tabel Simpleks

Berdasarkan perhitungan Tabel 2 yang sudah optimal, maka diperoleh penyelesaian untuk hijab kain adalah:

$$
\begin{aligned}
& x_{1}=4 \\
& x_{2}=46 \\
& Z=2.960 .000
\end{aligned}
$$

B. PerhitunganNon-Fuzzy untuk Hijab Instan

Berdasarkan analisa Permasalahan kedua dapat disederhanakan dalam bentuk matematis untuk persoalan maksimilisasi

Maksimumkan $\mathrm{Z}=90000 \mathrm{x}_{1}+75000 \mathrm{x}_{2}$

Kendala $\quad 2,5 \mathrm{x}_{1}+2,2 \mathrm{x}_{2} \leq 100$

$$
\begin{aligned}
& 15 \mathrm{x}_{1}+10 \mathrm{x}_{2} \leq 480 \\
& \mathrm{x}_{1}, \mathrm{x}_{2} \geq 0
\end{aligned}
$$

Hasil Perhitungan dengan Metode Simpleknya sebagai berikut: 
Tabel 3. Pemecahan Tabel Simpleks

\begin{tabular}{|c|c|c|c|c|c|c|c|c|}
\hline Basic & VB & $\mathbf{Z}$ & $x_{1}$ & $\mathbf{x}_{2}$ & $\mathbf{s}_{1}$ & $\mathbf{s}_{2}$ & NK & RASIO \\
\hline ITERASI (0) & $\mathbf{Z}$ & 1 & $\begin{array}{c}- \\
90000\end{array}$ & $\begin{array}{c}- \\
75000\end{array}$ & 0 & 0 & 0 & - \\
\hline $\mathbf{E V}=\mathrm{x}_{1}$ & $s_{1}$ & 0 & 2,5 & 2,2 & 1 & 0 & 100 & 40 \\
\hline \multirow[t]{2}{*}{$\mathbf{L V}=\mathbf{s}_{2}$} & $\mathbf{s}_{2}$ & 0 & 15 & 10 & 0 & 1 & 480 & 32 \\
\hline & VB & $\mathbf{Z}$ & $x_{1}$ & $\mathbf{x}_{2}$ & $s_{1}$ & $\mathbf{s}_{2}$ & NK & RASIO \\
\hline ITERASI (1) & $\mathbf{Z}$ & 1 & 0 & $\begin{array}{c}- \\
15000\end{array}$ & 0 & 6000 & 2880000 & - \\
\hline $\mathbf{E V}=\mathbf{x}_{2}$ & $s_{1}$ & 0 & 0 & 0,533 & 1 & $-0,167$ & 20 & 37,5 \\
\hline \multirow{2}{*}{$\mathbf{L V}=\mathbf{s}_{1}$} & $x_{1}$ & 0 & 1 & 0,667 & 0 & 0,067 & 32 & 48 \\
\hline & VB & $\mathbf{Z}$ & $x_{1}$ & $\mathbf{x}_{2}$ & $\mathbf{s}_{1}$ & $\mathbf{s}_{2}$ & NK & RASIO \\
\hline ITERASI (2) & $\mathbf{Z}$ & 1 & 0 & 0 & 28125 & 1312,5 & 3442500 & - \\
\hline \multirow[t]{2}{*}{ OPTIMAL } & $\mathbf{x}_{2}$ & 0 & 0 & 1 & 1,875 & $\begin{array}{c}- \\
0,3125\end{array}$ & 37,5 & \\
\hline & $\mathrm{x}_{1}$ & 0 & 1 & 0 & $-1,25$ & 0,275 & 7 & \\
\hline
\end{tabular}

Berdasarkan perhitungan tabel 3. yang sudah optimal, maka diperoleh penyelesaian untuk hijab kain adalah:

$$
\begin{aligned}
& x_{1}=7 \\
& x_{2}=37,5
\end{aligned}
$$

C. Perhitungan Fuzzy Linear Programming

Analisa masalah pertama dan kedua akan dibuat perhitungan Fuzzy Linear Programming ke dalam model matematis untuk hijab kain dan hijab instan.

Untuk Hijab Kain bentuk matematis pada FLP adalah:

Maksimumkan $\mathrm{z}=50000 \mathrm{x}_{1}+60000 \mathrm{x}_{2}$

Kendala $\quad 2 \mathrm{x}_{1}+2 \mathrm{x}_{2} \leqq 100$

$$
\begin{aligned}
& 5 x_{1}+10 x_{2} \leqq 480 \\
& x_{1}, x_{2} \geq 0
\end{aligned}
$$

Untuk Hijab Instan bentuk matematis pada FLP adalah:

Maksimumkan $\mathrm{z}=90000 \mathrm{x}_{1}+75000 \mathrm{x}_{2}$

Kendala $\quad 2,5 \mathrm{x}_{1}+2,2 \mathrm{x}_{2} \leqq 100$

$$
\begin{aligned}
& 15 \mathrm{x}_{1}+10 \mathrm{x}_{2} \leqq 480 \\
& \mathrm{x}_{1}, \mathrm{x}_{2}, \geq 0
\end{aligned}
$$

Kedua kendala di atas memiliki toleransi interval sesuai kasus di atas sebesar $15 \%$ untuk bahan kain dan $12,5 \%$ untuk waktu pembuatan. Sehingga toleransi interval di atas dapat dituliskan $\mathrm{p}_{1}=15$ dan $\mathrm{p}_{2}=60$.

Untuk Hijab Kain:

Maksimumkan $\mathrm{z}=50000 \mathrm{x}_{1}+60000 \mathrm{x}_{2}$ 
Kendala

$$
\begin{aligned}
& 2 x_{1}+2 x_{2} \leq 100+15 t \\
& 5 x_{1}+10 x_{2} \leq 480+60 t \\
& x_{1}, x_{2}, \geq 0
\end{aligned}
$$

Untuk Hijab Instan:

Maksimumkan $\mathrm{z}=90000 \mathrm{x}_{1}+75000 \mathrm{x}_{2}$

Kendala $\quad 2,5 \mathrm{x}_{1}+2,2 \mathrm{x}_{2} \leq 100+15 \mathrm{t}$

$$
\begin{aligned}
& 15 \mathrm{x}_{1}+10 \mathrm{x}_{2} \leq 480+60 \mathrm{t} \\
& \mathrm{x}_{1}, \mathrm{x}_{2}, \geq 0
\end{aligned}
$$

Jika $\mathrm{t}=0 \quad(\lambda=1)$, maka bentuk di atas menjadi bentuk matematis seperti pada pembahasan point 1) dan 2) di atas yang sudah diperoleh penyelesaiannya.

D. FLP untuk $\mathrm{t}=1$

Jika $t=1(\lambda=0)$, maka bentuk awal FLP hijab kain di atas dapat diubah menjadi:

Maksimumkan $\mathrm{z}=50000 \mathrm{x}_{1}+60000 \mathrm{x}_{2}$

Kendala $\quad 2 \mathrm{x}_{1}+2 \mathrm{x}_{2} \leq 115$

$$
\begin{aligned}
& 5 x_{1}+10 x_{2} \leq 540 \\
& x_{1}, x_{2} \geq 0
\end{aligned}
$$

\begin{tabular}{|c|c|c|c|c|c|c|c|c|}
\hline Keterangan & VB & $\mathbf{Z}$ & $x_{1}$ & $\mathbf{x}_{2}$ & $s_{1}$ & $\mathbf{s}_{2}$ & NK & RASIO \\
\hline ITERASI (0) & $\mathbf{Z}$ & 1 & $\begin{array}{c}- \\
50000\end{array}$ & $\begin{array}{c}- \\
60000\end{array}$ & 0 & 0 & 0 & - \\
\hline$E V=x_{2}$ & $s_{1}$ & 0 & 2 & 2 & 1 & 0 & 115 & 57,5 \\
\hline $\mathbf{L V}=\mathbf{s}_{2}$ & $\mathbf{s}_{2}$ & 0 & 5 & 10 & 0 & 1 & 540 & 54 \\
\hline & VB & $\mathbf{Z}$ & $x_{1}$ & $x_{2}$ & $\mathbf{s}_{1}$ & $\mathbf{s}_{2}$ & NK & RASIO \\
\hline ITERASI (1) & $\mathbf{Z}$ & 1 & $\begin{array}{c}- \\
20000\end{array}$ & 0 & 0 & 6000 & 3240000 & - \\
\hline$E V=x_{1}$ & $\mathbf{s}_{1}$ & 0 & 1 & 0 & 1 & $-0,2$ & 7 & 7 \\
\hline $\mathbf{L V}=\mathbf{s}_{1}$ & $x_{2}$ & 0 & 0,5 & 1 & 0 & 0,1 & 54 & 108 \\
\hline & VB & $\mathbf{Z}$ & $\mathrm{x}_{1}$ & $\mathbf{x}_{2}$ & $\mathbf{s}_{1}$ & $\mathbf{s}_{2}$ & NK & RASIO \\
\hline ITERASI (2) & $\mathbf{Z}$ & 1 & 0 & 0 & 20000 & 2000 & 3380000 & - \\
\hline OPTIMAL & $x_{1}$ & 0 & 1 & 0 & 1 & $-0,2$ & 7 & \\
\hline & $x_{2}$ & 0 & 0 & 1 & $-0,5$ & 0,2 & 50,5 & \\
\hline
\end{tabular}

Diubah ke dalam Bentuk standar:

Maksimumkan $\mathrm{z}=50000 \mathrm{x}_{1}+60000 \mathrm{x}_{2}+0 \mathrm{~s}_{1}+0 \mathrm{~s}_{2}$

Kendala $\quad 2 \mathrm{x}_{1}+2 \mathrm{x}_{2}+\mathrm{s}_{1} \quad=115$

$$
\begin{aligned}
& 5 x_{1}+10 x_{2}+s_{2}=540 \\
& x_{1}, x_{2}, s_{1}, s_{2} \geq 0
\end{aligned}
$$

Tabel 4. Pemecahan Tabel Simpleks 
Berdasarkan perhitungan Tabel 4 yang sudah optimal, maka diperoleh penyelesaian untuk hijab kain adalah:

$$
\begin{aligned}
& x_{1}=7 \\
& x_{2}=50,5
\end{aligned}
$$

Bentuk matematis untuk hijab instan adalah:

Maksimumkan $\mathrm{Z}=90000 \mathrm{x}_{1}+75000 \mathrm{x}_{2}$

Kendala $\quad 2,5 \mathrm{x}_{1}+2,2 \mathrm{x}_{2} \leq 115$

$$
\begin{aligned}
& 15 x_{1}+10 x_{2} \leq 540 \\
& x_{1}, x_{2} \geq 0
\end{aligned}
$$

Yang juga diubah ke dalam Bentuk standar:

Maksimumkan $\mathrm{Z}=90000 \mathrm{x}_{1}+75000 \mathrm{x}_{2}+0 \mathrm{~s}_{1}+0 \mathrm{~s}_{2}$

Kendala

\begin{tabular}{|c|c|c|c|c|c|c|c|c|}
\hline Keterangan & VB & $\mathbf{Z}$ & $\mathbf{x}_{1}$ & $x_{2}$ & $s_{1}$ & $\mathbf{s}_{2}$ & NK & RASIO \\
\hline ITERASI (0) & $\mathbf{Z}$ & 1 & $\begin{array}{c}- \\
90000\end{array}$ & $\begin{array}{c}- \\
75000\end{array}$ & 0 & 0 & 0 & - \\
\hline $\mathbf{E V}=\mathbf{x}_{1}$ & $\mathbf{s}_{\mathbf{1}}$ & 0 & 2,5 & 2,2 & 1 & 0 & 115 & 46 \\
\hline \multirow[t]{2}{*}{$\mathbf{L V}=\mathbf{s}_{2}$} & $\mathbf{s}_{2}$ & 0 & 15 & 10 & 0 & 1 & 540 & 36 \\
\hline & VB & $\mathbf{Z}$ & $\mathrm{x}_{1}$ & $\mathrm{x}_{2}$ & $\mathrm{~s}_{1}$ & $\mathrm{~s}_{2}$ & NK & RASIO \\
\hline ITERASI (1) & $\mathbf{Z}$ & 1 & 0 & $\begin{array}{c}- \\
15000\end{array}$ & 0 & 6000 & 32400000 & - \\
\hline $\mathbf{E V}=\mathbf{x}_{2}$ & $\mathbf{s}_{1}$ & 0 & 0 & 0,533 & 1 & $-0,167$ & 25 & 46,875 \\
\hline \multirow[t]{2}{*}{$\mathbf{L V}=\mathbf{s}_{1}$} & $x_{1}$ & 0 & 1 & 0,667 & 0 & 0,067 & 36 & 54 \\
\hline & VB & $\mathbf{Z}$ & $\mathrm{x}_{1}$ & $\mathrm{x}_{2}$ & $\mathrm{~s}_{1}$ & $\mathrm{~s}_{2}$ & NK & RASIO \\
\hline ITERASI (2) & $\mathbf{Z}$ & 1 & 0 & 0 & 28125 & 1312,5 & 3943125 & - \\
\hline \multirow[t]{2}{*}{ OPTIMAL } & $\mathbf{x}_{2}$ & 0 & 0 & 1 & 1,875 & $\begin{array}{c}- \\
0,3125\end{array}$ & 46,875 & \\
\hline & $\mathbf{x}_{1}$ & 0 & 1 & 0 & $-1,25$ & 0,275 & 4,75 & \\
\hline
\end{tabular}

$$
\begin{aligned}
& 2,5 x_{1}+2,2 x_{2}+s_{1}=115 \\
& 15 x_{1}+10 x_{2}+s_{2}=540 \\
& x_{1}, x_{2}, s_{1}, s_{2} \geq 0
\end{aligned}
$$

Penyelesaian dengan metode simplek akan menghasilkan

\section{Tabel 5. Pemecahan Tabel Simpleks}

Berdasarkan perhitungan Tabel 5 yang sudah optimal, maka diperoleh penyelesaian untuk hijab kain adalah:

$$
\begin{aligned}
& x_{1}=4,75 \\
& x_{2}=46,875
\end{aligned}
$$

E. Penyelesaian FLP untuk Hijab Kain 
Dari hasil $\mathrm{t}=0$ dan $\mathrm{t}=1$ dapat ditentukan nilai $\mathrm{p}_{0}$ yang diperoleh dari pengurangan fungsi obyektifnya $t_{1}-t_{0}$, yang menghasilkan $p_{0}=3380000-2960000=420000$.

\section{Tahap 1}

Menyelesaikan linier programming

Min : r=R1

Dengan batasan

$$
\begin{aligned}
& -420000 \lambda+50000 \mathrm{x}_{1}+60000 \mathrm{x}_{2}-\mathrm{s}_{1} \quad+\mathrm{R} 1=2960000 \\
& 15 \lambda+2 x_{1}+2 x_{2} \quad+s_{2} \quad=115 \\
& 60 \lambda+5 x_{1}+10 x_{2} \quad+s_{3}=540 \\
& \lambda, \mathrm{x}_{1}, \mathrm{x}_{2}, \mathrm{~s}_{1}, \mathrm{~s}_{2}, \mathrm{~s}_{3} \geq 0
\end{aligned}
$$

\begin{tabular}{|c|c|c|c|c|c|c|c|c|c|c|c|}
\hline Basic & VB & $\mathbf{r}$ & $\Lambda$ & $\mathbf{x}_{1}$ & $\mathbf{x}_{2}$ & $\mathbf{s}_{1}$ & $\mathbf{s}_{2}$ & $\mathbf{s}_{3}$ & $\mathbf{R}_{1}$ & SOLUSI & RASIO \\
\hline $\begin{array}{l}\text { Iterasi } \\
(0)\end{array}$ & $\mathbf{R}$ & 1 & $\begin{array}{c}- \\
480000\end{array}$ & 50000 & 600000 & -1 & 0 & 0 & 0 & 2960000 & - \\
\hline $\mathrm{Ev}=\mathbf{x}_{2}$ & $\mathbf{R}_{1}$ & 0 & $\begin{array}{c}- \\
480000\end{array}$ & 50000 & 60000 & -1 & 0 & 0 & 1 & 2960000 & 49,33 \\
\hline \multirow[t]{3}{*}{$\mathrm{Lv}=\mathbf{R}_{\mathbf{1}}$} & $\mathbf{s}_{2}$ & 0 & 15 & 2 & 2 & 0 & 1 & 0 & 0 & 115 & 57,5 \\
\hline & $s_{3}$ & 0 & 60 & 5 & 10 & 0 & 0 & 1 & 0 & 540 & 54 \\
\hline & VB & $\mathbf{r}$ & $\Lambda$ & $\mathbf{x}_{1}$ & $\mathbf{x}_{2}$ & $s_{1}$ & $\mathbf{s}_{2}$ & $\mathbf{s}_{3}$ & $\mathbf{R}_{1}$ & SOLUSI & RASIO \\
\hline $\begin{array}{c}\text { Iterasi ( } \\
1)\end{array}$ & $\mathbf{R}$ & 1 & 0 & 0 & 0 & 0 & 0 & 0 & -1 & 0 & - \\
\hline \multirow[t]{3}{*}{ Optimal } & $\mathbf{x}_{2}$ & 0 & -7 & 0,833 & 1 & 0 & 0 & 0 & 0 & 49,33 & \\
\hline & $\mathbf{s}_{2}$ & 0 & 29 & 0,33 & 0 & 0 & 1 & 0 & 0 & 16,33 & \\
\hline & $\mathbf{s}_{3}$ & 0 & 130 & $-3,33$ & 0 & 0 & 0 & 1 & 0 & 46,67 & \\
\hline
\end{tabular}

Tabel 6. Tabel simplek awal

\section{Tahap 2}

Menyelesaikan linier programming

Maks : $\quad \mathrm{z}=\lambda$

Dengan batasan

$$
\begin{aligned}
& -7 \lambda+0,83 \mathrm{x}_{1}+\mathrm{x}_{2} \quad=49,33 \\
& 29 \lambda+0,33 \mathrm{x}_{1}+\mathrm{s}_{2}=16,33 \\
& 130 \lambda-3,33 \mathrm{x}_{1} \quad+\mathrm{s}_{3}=46,67 \\
& \lambda, \mathrm{x}_{1}, \mathrm{x}_{2}, \mathrm{~s}_{2}, \mathrm{~s}_{3} \geq 0
\end{aligned}
$$

Tabel 7. Pemecahan Tabel simpleks

\begin{tabular}{ccccccccccc}
\hline Basic & $\mathbf{V B}$ & $\mathbf{R}$ & $\boldsymbol{\lambda}$ & $\mathbf{x}_{\mathbf{1}}$ & $\mathbf{x}_{\mathbf{2}}$ & $\mathbf{s}_{\mathbf{1}}$ & $\mathbf{s}_{\mathbf{2}}$ & $\mathbf{s}_{\mathbf{3}}$ & SOLUSI & RASIO \\
\hline Iterasi $(1)$ & $\mathbf{Z}$ & 1 & -1 & 0 & 0 & 0 & 0 & 0 & 0 & - \\
\hline $\mathrm{Ev}=\lambda$ & $\mathbf{x}_{\mathbf{2}}$ & 0 & -7 & 0,833 & 1 & 0 & 0 & 0 & 49,33 & - \\
\hline $\mathbf{L v}=\mathbf{s}_{\mathbf{3}}$ & $\mathbf{s}_{\mathbf{2}}$ & 0 & 29 & 0,33 & 0 & 0 & 1 & 0 & 16,33 & 0,56 \\
\hline & $\mathbf{s}_{\mathbf{3}}$ & 0 & 130 & $-3,33$ & 0 & 0 & 0 & 1 & 46,67 & 0,36 \\
\hline
\end{tabular}




\begin{tabular}{ccccccccccc}
\hline & $\mathbf{V B}$ & $\mathbf{R}$ & $\boldsymbol{\lambda}$ & $\mathbf{x}_{\mathbf{1}}$ & $\mathbf{x}_{\mathbf{2}}$ & $\mathbf{s}_{\mathbf{1}}$ & $\mathbf{s}_{\mathbf{2}}$ & $\mathbf{s}_{\mathbf{3}}$ & SOLUSI & RASIO \\
\hline Iterasi ( 1) & $\mathbf{Z}$ & 1 & 0 & $-0,03$ & 0 & 0 & 0 & 0,01 & 0,36 & - \\
\hline $\mathrm{Ev}=\mathbf{x}_{\mathbf{1}}$ & $\mathbf{x}_{\mathbf{2}}$ & 0 & 0 & 0,65 & 1 & 0 & 0 & 0,05 & 51,84 & 79,29 \\
\hline $\operatorname{Lv}=\mathbf{S}_{2}$ & $\mathbf{s}_{\mathbf{2}}$ & 0 & 0 & 1,07 & 0 & 0 & 1 & - & 5,29 & 5,51 \\
& & & & & & & & 0,22 & & \\
& $\boldsymbol{\lambda}$ & 0 & 1 & $-0,03$ & 0 & 0 & 0 & 0,01 & 0,36 & - \\
\hline Iterasi ( 1) & $\mathbf{Z}$ & 1 & 0 & 0 & 0 & 0 & 0,024 & 0 & 0,5 & - \\
\hline Optimal & $\mathbf{x}_{\mathbf{2}}$ & 0 & 0 & 0 & 1 & 0 & $-0,61$ & 0,19 & 48,23 & - \\
\hline & $\mathbf{x}_{\mathbf{1}}$ & 0 & 0 & 1 & 0 & 0 & 0,93 & $-0,2$ & 5,517 & - \\
\hline & $\boldsymbol{\lambda}$ & 0 & 1 & 0 & 0 & 0 & 0,024 & 0 & 0,5 & -
\end{tabular}

F. Penyelesaian FLP untuk Hijab Instan

Dari hasil $\mathrm{t}=0$ dan $\mathrm{t}=1$ dapat ditentukan nilai $\mathrm{p}_{0}$ yang diperoleh dari pengurangan fungsi obyektifnya $t_{1}-t_{0}$, yang menghasilkan $p_{0}=3943125-3442500=500625$.

\section{Tahap 1}

Dengan batasan

$$
\begin{array}{cccc}
-500625 \lambda+90000 x_{1}+75000 x_{2}-s_{1} & +R_{1} & =3442500 \\
15 \lambda+2,5 x_{1}+2,2 x_{2}+s_{2} & =115 \\
60 \lambda+ & 15 x_{1}+10 x_{2} & +s_{3} & =540 \\
\lambda, x_{1}, x_{2}, s_{1}, s_{2}, s_{3} \geq 0 & &
\end{array}
$$

\begin{tabular}{|c|c|c|c|c|c|c|c|c|c|c|c|}
\hline Basic & VB & $\mathbf{R}$ & $\lambda$ & $\mathbf{x}_{1}$ & $\mathbf{x}_{2}$ & $\mathbf{s}_{1}$ & $\mathbf{s}_{2}$ & $\mathbf{s}_{3}$ & $\mathbf{R}_{1}$ & $\begin{array}{c}\text { SOLUS } \\
\text { I }\end{array}$ & $\begin{array}{c}\text { RASI } \\
\text { O }\end{array}$ \\
\hline Iterasi (0) & $\mathbf{R}$ & 1 & $\begin{array}{c}- \\
500625\end{array}$ & $\begin{array}{c}9000 \\
0\end{array}$ & $\begin{array}{c}7500 \\
0\end{array}$ & -1 & 0 & 0 & 0 & 3442500 & - \\
\hline $\mathrm{Ev}=\mathbf{x}_{\mathbf{1}}$ & R1 & 0 & $\begin{array}{c}- \\
500625\end{array}$ & $\begin{array}{c}9000 \\
0\end{array}$ & $\begin{array}{c}7500 \\
0\end{array}$ & -1 & 0 & 0 & 1 & 3442500 & 38,25 \\
\hline $\mathrm{Lv}=\mathbf{S}_{\mathbf{3}}$ & $\mathbf{S}_{2}$ & 0 & 15 & 2,5 & 2,2 & 0 & 1 & 0 & 0 & 115 & 46 \\
\hline & $\begin{array}{c}\mathbf{S}_{\mathbf{3}} \\
\text { VB }\end{array}$ & $\begin{array}{l}0 \\
\mathbf{R}\end{array}$ & $\begin{array}{c}60 \\
\lambda\end{array}$ & $\begin{array}{l}15 \\
\mathbf{x}_{1}\end{array}$ & $\begin{array}{l}10 \\
\mathbf{x}_{2}\end{array}$ & $\begin{array}{c}0 \\
\mathbf{s}_{1}\end{array}$ & $\begin{array}{c}0 \\
\mathbf{s}_{2}\end{array}$ & $\frac{1}{\mathbf{s}_{3}}$ & $\begin{array}{c}0 \\
\mathbf{R}_{\mathbf{1}}\end{array}$ & $\begin{array}{c}540 \\
\text { SOLUS } \\
\text { I }\end{array}$ & $\begin{array}{c}36 \\
\text { RASI } \\
\mathbf{O}\end{array}$ \\
\hline Iterasi ( 1) & $\mathbf{r}$ & 1 & $\begin{array}{c}- \\
860625\end{array}$ & 0 & $\begin{array}{c}1500 \\
0\end{array}$ & -1 & 0 & -6000 & 0 & 202500 & - \\
\hline $\mathrm{Ev}=\mathbf{x}_{\mathbf{2}}$ & $\mathbf{R}_{1}$ & 0 & $\begin{array}{c}- \\
860625\end{array}$ & 0 & $\begin{array}{c}1500 \\
0\end{array}$ & -1 & 0 & -6000 & 1 & 202500 & 13,5 \\
\hline $\mathrm{Lv}=\mathbf{R}_{\mathbf{1}}$ & $\begin{array}{l}\mathbf{s}_{2} \\
\mathbf{x}_{1}\end{array}$ & $\begin{array}{l}0 \\
0\end{array}$ & $\begin{array}{l}5 \\
4\end{array}$ & $\begin{array}{l}0 \\
1\end{array}$ & $\begin{array}{l}0,53 \\
0,67\end{array}$ & $\begin{array}{l}0 \\
0\end{array}$ & $\begin{array}{l}1 \\
0\end{array}$ & $\begin{array}{c}-0,17 \\
0,07\end{array}$ & $\begin{array}{l}0 \\
0\end{array}$ & $\begin{array}{l}25 \\
36\end{array}$ & $\begin{array}{c}46,88 \\
54\end{array}$ \\
\hline & VB & $\mathbf{R}$ & $\lambda$ & $\mathrm{x}_{1}$ & $\mathbf{x}_{2}$ & $s_{1}$ & $\mathbf{s}_{2}$ & $\mathbf{s}_{3}$ & $\mathbf{R}_{1}$ & $\begin{array}{c}\text { SOLUS } \\
\text { I }\end{array}$ & $\begin{array}{c}\text { RASI } \\
\text { O }\end{array}$ \\
\hline Iterasi (2) & $\mathbf{r}$ & 1 & 0 & 0 & 0 & 0 & 0 & 0 & -1 & 0 & \\
\hline Optimal & $\mathbf{x}_{2}$ & 0 & $-57,38$ & 0 & 1 & 0 & 0 & $-0,4$ & 0 & 13,5 & \\
\hline & $s_{2}$ & 0 & 35,60 & 0 & 0 & 0 & 1 & 0,05 & 0 & 17,8 & \\
\hline & $\mathbf{x}_{1}$ & 0 & 42,25 & 1 & 0 & 0 & 0 & 0,33 & 0 & 27 & \\
\hline
\end{tabular}

Tabel 8. Tabel simplek awal 


\section{Tahap 2}

Menyelesaikan linier programming

Maks : $\quad \mathrm{z}=\lambda$

Dengan batasan

$$
\begin{aligned}
& -57,38 \lambda+\mathrm{x}_{2}-0,4 \mathrm{~s}_{3} \quad=13,5 \\
& 35,6 \lambda+s_{2}+0,05 s_{3}=17,8 \\
& 42,25 \lambda+x_{1}+0,33 s_{3}=27 \\
& \lambda, \mathrm{x}_{1}, \mathrm{x}_{2}, \mathrm{~s}_{2}, \mathrm{~s}_{3} \geq 0
\end{aligned}
$$

Tabel 9. Tabel simpleks

\begin{tabular}{ccccccccccc}
\hline Keterangan & $\mathbf{V B}$ & $\mathbf{Z}$ & $\boldsymbol{\Lambda}$ & $\mathbf{x}_{\mathbf{1}}$ & $\mathbf{x}_{\mathbf{2}}$ & $\mathbf{s}_{\mathbf{1}}$ & $\mathbf{s}_{\mathbf{2}}$ & $\mathbf{s}_{\mathbf{3}}$ & SOLUSI & RASIO \\
\hline Iterasi ( 1) & $\mathbf{Z}$ & 1 & -1 & 0 & 0 & 0 & 0 & 0 & 0 & - \\
\hline Ev $=\lambda$ & $\mathbf{x}_{\mathbf{2}}$ & 0 & - & 0 & 1 & 0 & 0 & $-0,4$ & 13,5 & - \\
& & & 57,38 & & & & & & & \\
\hline Lv $=\mathbf{s}_{\mathbf{2}}$ & $\mathbf{s}_{\mathbf{2}}$ & 0 & 35,60 & 0 & 0 & 0 & 1 & 0,05 & 17,8 & 0,5 \\
\hline & $\mathbf{x}_{\mathbf{1}}$ & 0 & 42,25 & 1 & 0 & 0 & 0 & 0,33 & 27 & 0,64 \\
\hline & $\mathbf{V B}$ & $\mathbf{R}$ & $\boldsymbol{\Lambda}$ & $\mathbf{x}_{\mathbf{1}}$ & $\mathbf{x}_{\mathbf{2}}$ & $\mathbf{s}_{\mathbf{1}}$ & $\mathbf{s}_{\mathbf{2}}$ & $\mathbf{s}_{\mathbf{3}}$ & SOLUSI & $\mathbf{R A S I O}$ \\
\hline Iterasi ( 1) & $\mathbf{Z}$ & 1 & 0 & 0 & 0 & 0 & 0,03 & 0 & 0,5 & - \\
\hline Optimum & $\mathbf{x}_{\mathbf{2}}$ & 0 & 0 & 0 & 1 & 0 & 1,61 & - & 42,19 & - \\
& & & & & & & & 0,32 & & - \\
\hline & $\boldsymbol{\lambda}$ & 0 & 1 & 0 & 0 & 0 & 0,03 & 0 & 0,5 & - \\
\hline & $\mathbf{x}_{\mathbf{1}}$ & 0 & 0 & 1 & 0 & 0 & - & 0,28 & 5,87 & - \\
& & & & & & & 1,19 & & & \\
\hline
\end{tabular}

G. Penyelesaian FLP dengan program LINDO

1. Analisa kasus [1].

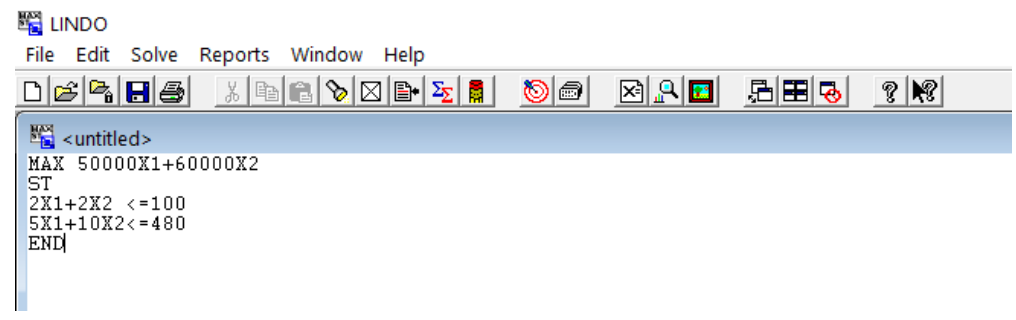

Gambar 1. Input program LINDO kasus [1]

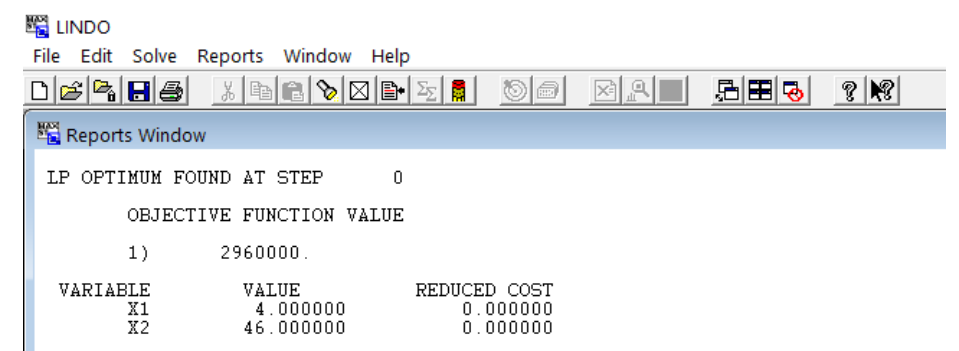

Gambar 2. Output LINDO kasus [1]. 
Menurut gambar 2, Objective function value atau fungsi tujuan ditempatkan pada baris 1) yaitu 2960000. Variabel keputusan pada output LINDO ditandai dengan label Variable.Karena kasus [1] mempunyai dua variabel keputusan dengan dengan nilai optimal $\mathrm{x}_{1}$ yaitu 4 dan $\mathrm{x}_{2}$ yaitu 46 dapat dilihat kecocokan antara hasil yang diberikan antara perhitungan dengan tabel simpleks dan sofware Lindo.

2. Analisa kasus [2].

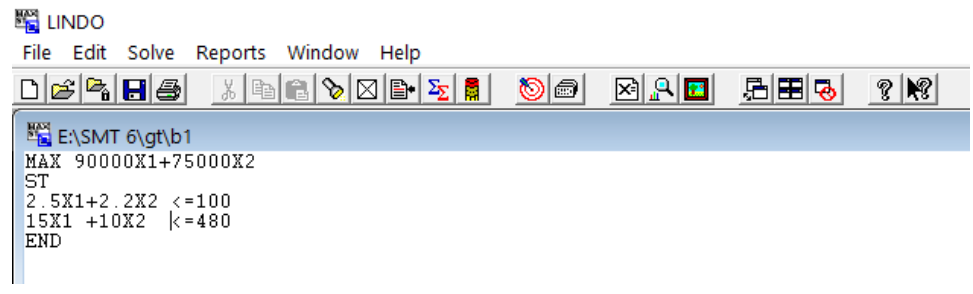

Gambar 3. Input program LINDO kasus [2]

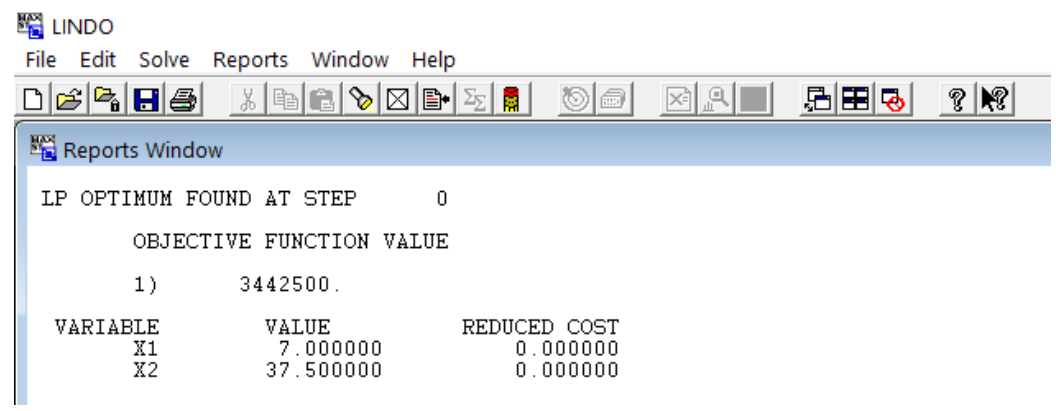

Gambar 4. Output LINDO kasus [2]

Menurut gambar 4, Objective funnction value atau fungsi tujuan ditempatkan pada baris 1) yaitu 3442500. Variabel keputusan pada output LINDO ditandai dengan label Variable.Karena kasus [2] mempunyai dua variabel keputusan dengan dengan nilai optimal $\mathrm{x}_{1}$ yaitu 7 dan $\mathrm{x}_{2}$ yaitu 37,5 dapat dilihat kecocokan antara hasil yang diberikan antara perhitungan dengan tabel simpleks dan sofware LINDO.

3. Analisa kasus [3].

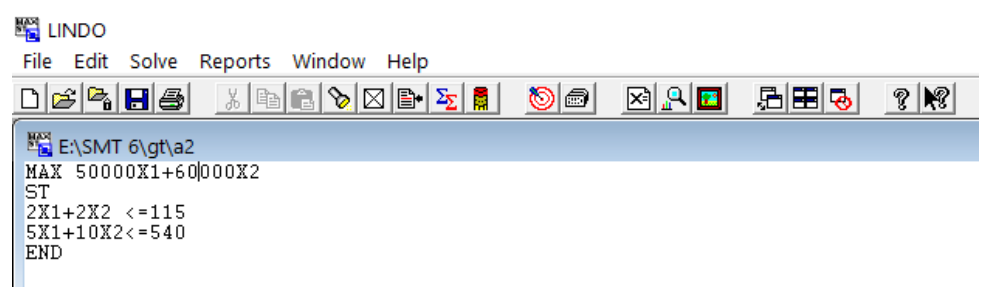

Gambar 5. Input program LINDO kasus [3] 


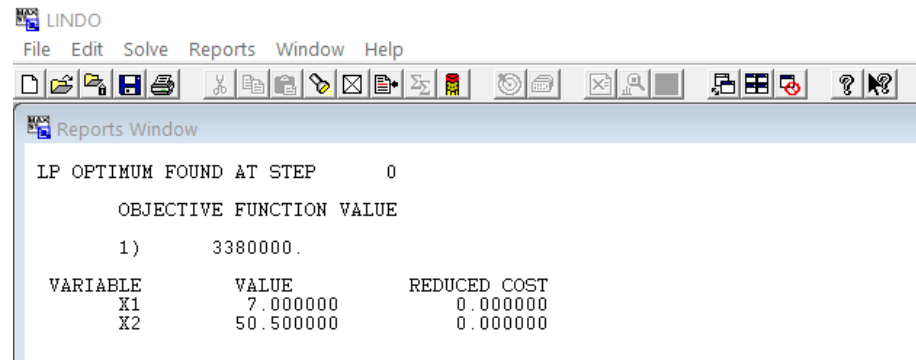

\section{Gambar 6. Output LINDO kasus [3]}

Menurut gambar 6, Objective funnction value atau fungsi tujuan ditempatkan pada baris 1) yaitu 3380000. Variabel keputusan pada output LINDO ditandai dengan label Variable.Karena kasus [3] mempunyai dua variabel keputusan dengan dengan nilai optimal $\mathrm{x}_{1}$ yaitu 7 dan $\mathrm{x}_{2}$ yaitu 50.5 dapat dilihat kecocokan antara hasil yang diberikan antara perhitungan dengan tabel simpleks dan sofware LINDO

4. Analisa kasus [4].

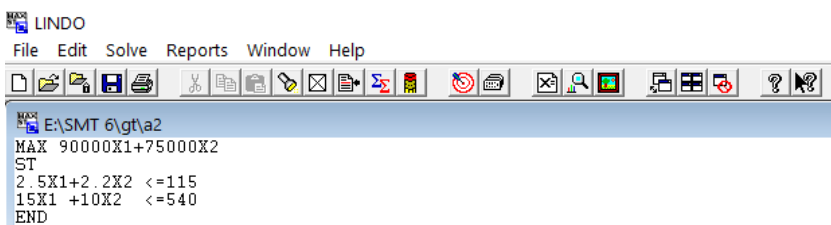

Gambar 7.Input program LINDO kasus [4]

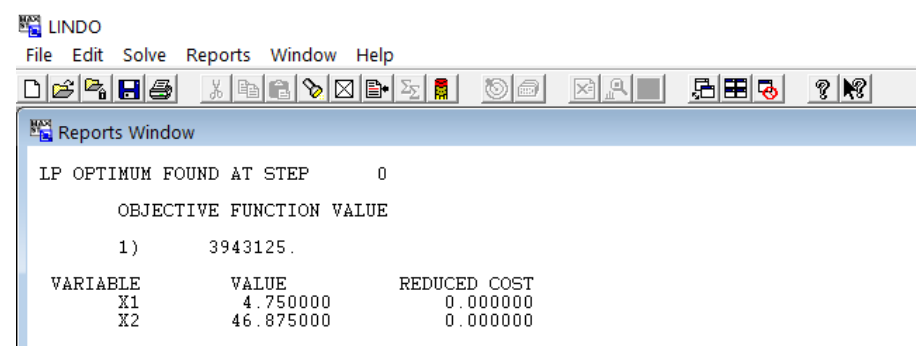

\section{Gambar 8. Output LINDO kasus [4]}

Menurut gambar 8, Objective funnction value atau fungsi tujuan ditempatkan pada baris 1) yaitu 3943125. Value yaitu variabel keputusan pada output LINDO ditandai dengan label Variable.Karena kasus [4] mempunyai dua variabel keputusan dengan dengan nilai optimal $\mathrm{x}_{1}$ yaitu 4,75 dan $\mathrm{x}_{2}$ yaitu 46,875 dapat dilihat kecocokan antara hasil yang diberikan antara perhitungan dengan tabel simpleks dan sofware LINDO.

5. Analisa kasus [5].

Tahap 1: 


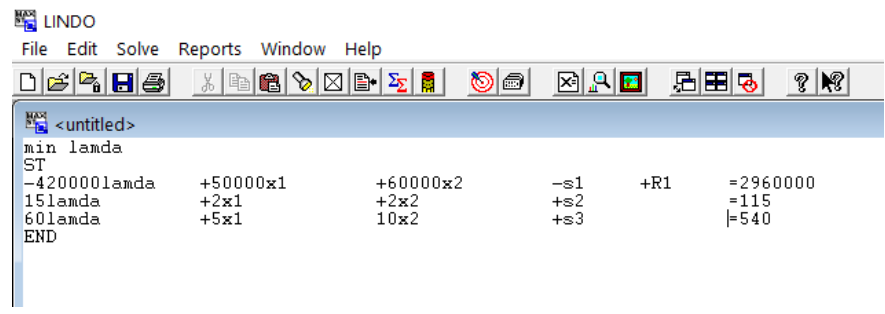

\section{Gambar 9. Input program LINDO kasus [5]}

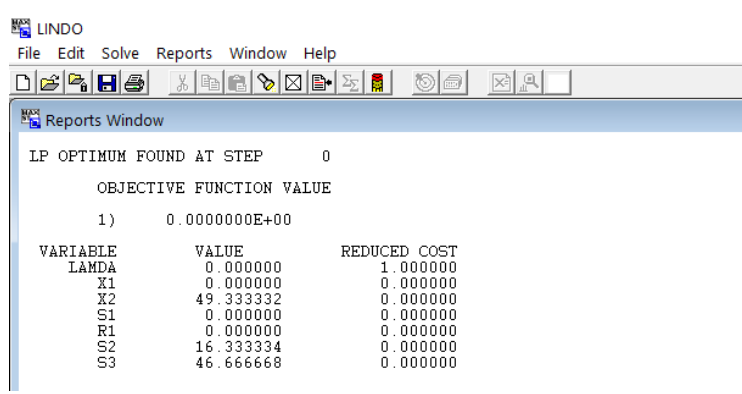

Gambar 10. Output LINDO kasus [5]

Lalu klik tombol reports $\rightarrow$ klik tableau .

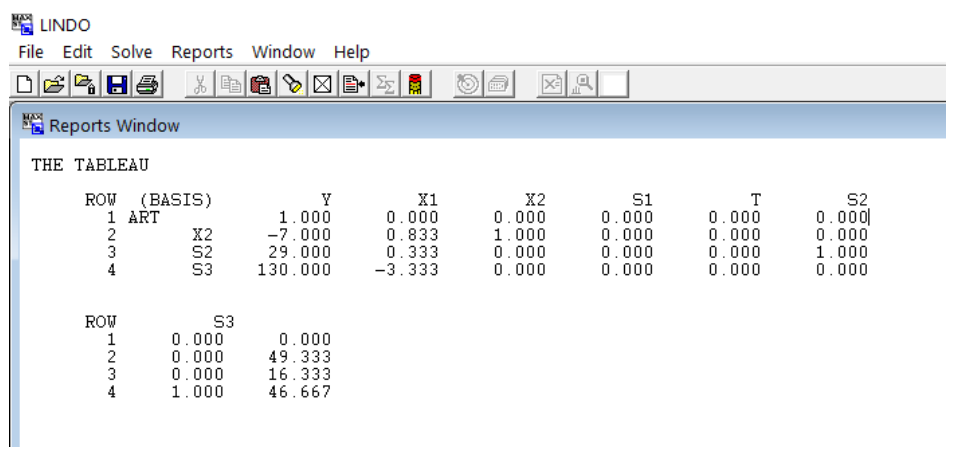

\section{Gambar 11. Output tableau}

Masuk ke persamaaan selanjutnya

Tahap 2:

Hasil dari gambar 11 kita membuat persamaan memaksimalkan

Proses pemasukan data gambar 11. pemograman linier akan tampak sebagai berikut.

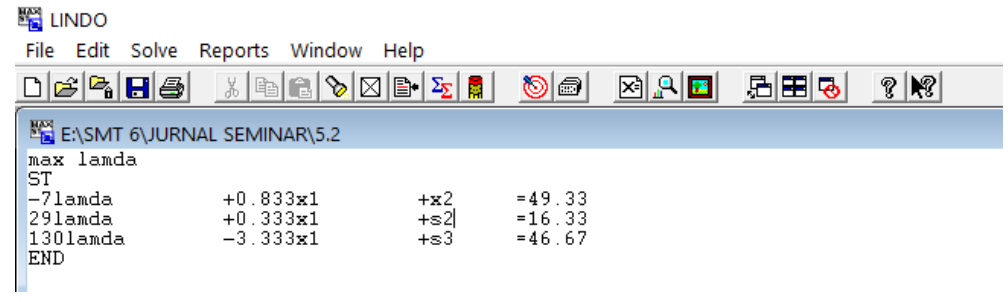

Gambar 12. Tampilan scrip dari gambar 11 


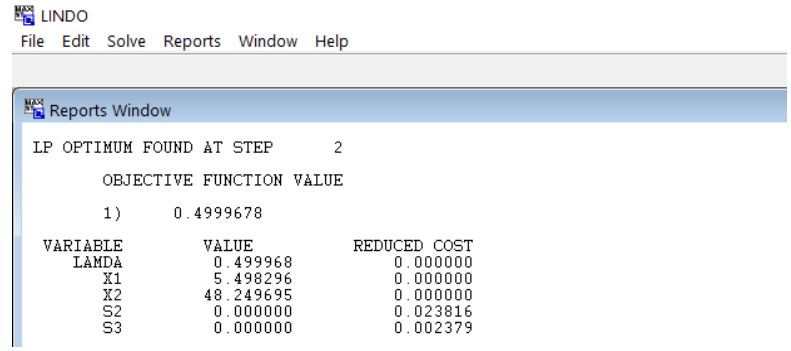

Gambar 13. Output LINDO

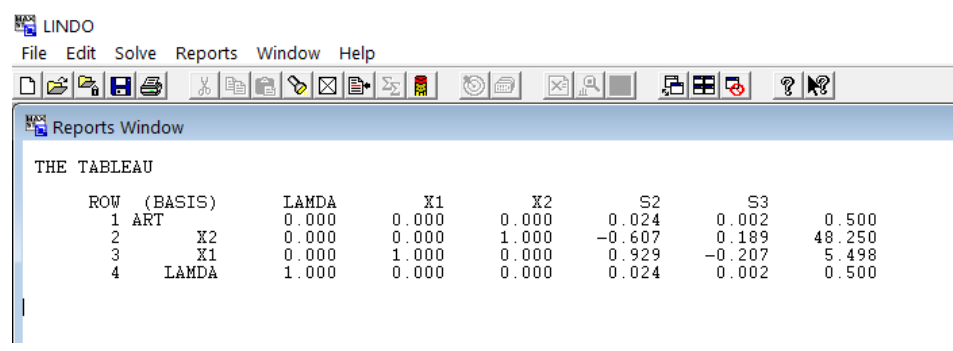

Gambar 14. Output tableau

Menurut gambar 13. Variabel keputusan pada output LINDO ditandai dengan label Variable.Karena mempunyai dua variabel keputusan dengan dengan nilai optimal $\mathrm{x}_{1}$ yaitu 5,498 dan $\mathrm{x}_{2}$ yaitu 48,25 dan $\lambda=0,5$ dapat dilihat kecocokan antara hasil yang diberikan antara perhitungan dengan tabel simpleks dan sofware LINDO.

6. Analisa kasus [6].

Tahap 1:

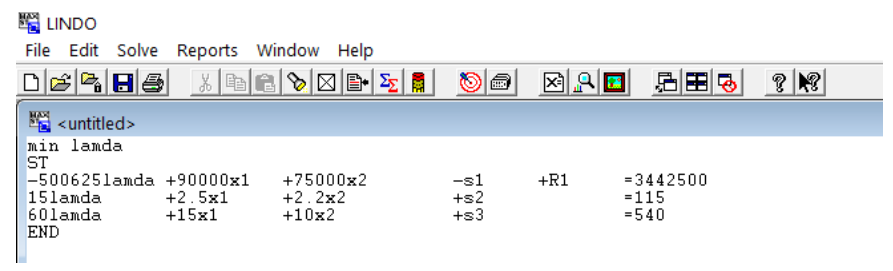

\section{Gambar 15. Input program LINDO kasus [6]}

매맴 LINDO

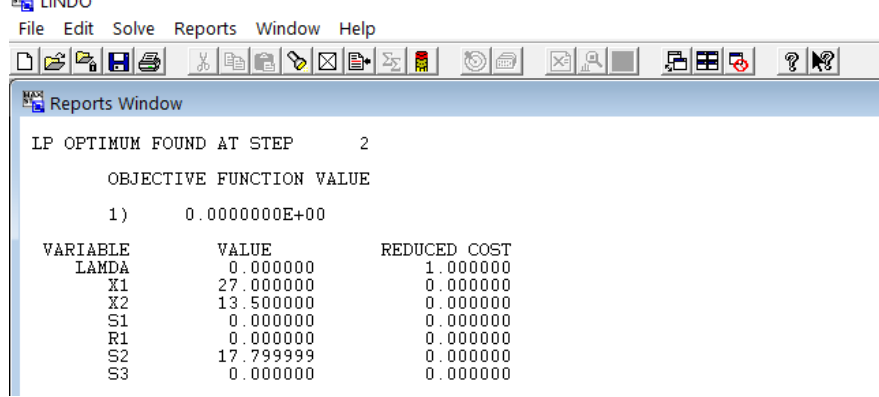

\section{Gambar 16. Output lindo kasus [6]}

Lalu klik tombol reports $\rightarrow$ klik tableau . 


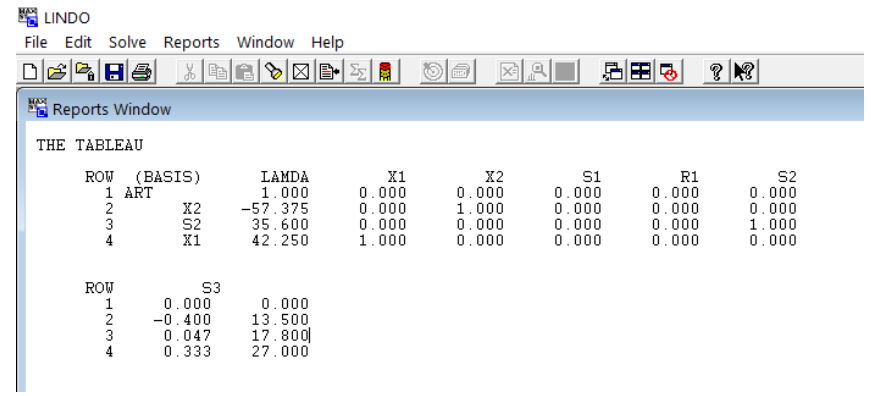

Gambar 17. Output tableau

Masuk ke persamaaan selanjutnya

Tahap 2:

Hasil dari gambar 17 kita membuat persamaan memaksimalkan

Proses pemasukan data gambar 17 pemograman linier akan tampak sebagai berikut.

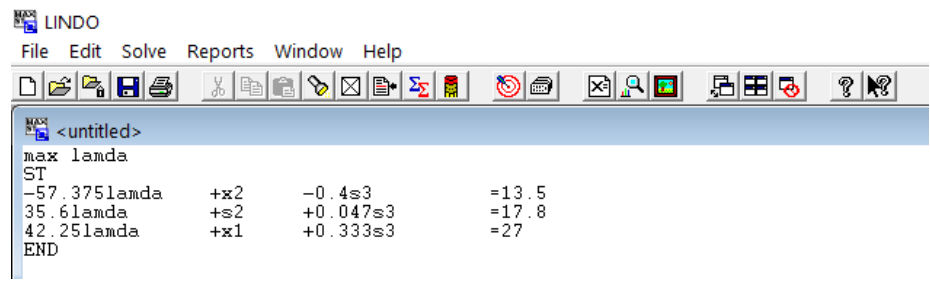

\section{Gambar 18. Tampilan scrip dari gambar 17}

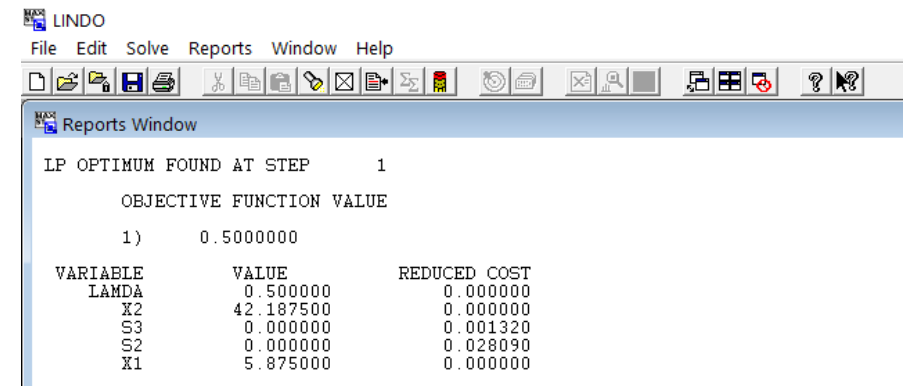

\section{Gambar 19. Output LINDO}

팸 LINDO

File Edit Solve Reports Window Help

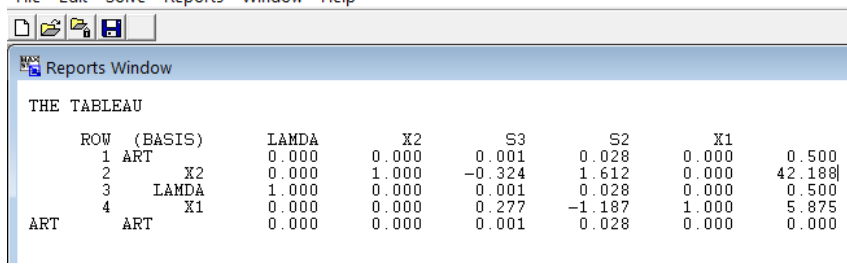

Gambar 20. Output tableau

Menurut gambar 20 Variabel keputusan pada output LINDO ditandai dengan label Variable.Karena mempunyai dua variabel keputusan dengan dengan nilai optimal $\mathrm{x}_{1}$ yaitu 5,875 dan $\mathrm{x}_{2}$ yaitu 42,188 dan $\lambda=0,5$ dapat dilihat kecocokan antara hasil yang diberikan antara perhitungan dengan tabel simpleks dan sofware LINDO. 


\section{SIMPULAN DAN SARAN}

Penyelesaian menggunakan metode simpleks dan program LINDO di atas terbukti bahwa dengan FLP akan menghasilkan solusi yang lebih optimal dibandingkan dengan solusi Pemrograman Linier yang standar. Dengan Program Linear biasa akan menghasilkan keuntungan yang maksimal jika memproduksi hijab kain sebanyak 4 buah dan hijab pashmina sebanyak 46 buah dengan pendapatam Rp 2.960 .000 per hari. Menggunakan FLP akan mendapatkan keuntungan yang maksimal dengan memproduksi hijab pasmina instan sebanyak 5 buah dan hijab pashmina sebanyak 48 buah dengan keuntungan Rp. 3.130.000 per hari dan tidak melanggar batasan kendala yang ada.

Begitu juga untuk hijab instan. Dengan Program Linier biasa akan menghasilkan pendapatan yang maksimal jika memproduksi hijab pasmina instan sebanyak 7 buah dan hijab pashmina sebanyak 37 buah dengan pendapatan Rp.3.405.000 per hari, sedangkan FLP akan mendapatkan keuntungan yang maksimal dengan memproduksi hijab pasmina instan sebanyak 5 buah dan hijab pashmina sebanyak 42 buah dengan keuntungan Rp.3.600.000 per hari dan tidak melanggar batasan kendala yang ada.

Penelitian ini, masih dapat dikembangkan sehingga disarankan untuk penelitian selanjutnya agar menggunakan program yang penyelesaian lebih cepat dan hasil akurat, serta dapat diaplikasikan dalam bidang ilmu lainnya.

\section{DAFTAR PUSTAKA}

Amindo, R (2006). Penentuan Kapasitas Optimal Produksi CPO (Crude Plam Oil) di Pabrik Kelapa Sawit PT.Andira Agro dengan menggunakan Goal Programming.Skripsi Bogor:Fakultas Teknologi Pertanian Institut Pertanian Bogor

Berlianty, Intan. (2010). Teknik-Teknik Optimasi Heuristik.Yogyakarta:Graha Ilmu

Haryati Ekaningsih. (2011) Proses Untuk Menyelesaikan Masalah Fullyfuzzy Linear Programming.Universitas Negeri Yogyakarta. Yogyakarta

Martini. (2017). Optimasi Produksi Hijab Dengan Fuzzy Linier Programming. MATEMATIKA, 3(1). pp. 65-72.

Kusumadewi, S. dan Hari, P. (2004). Aplikasi Logika Fuzzy untuk Pendukung Keputusan. Yogyakarta: Graha Ilmu

Kuswardi, Y. (2011). Program Linier.Surakarta:UNS Press

Siswanto. (2007). Operations Research.Jakarta:Erlangga

Taha, H., A. (2007). Operations Research: An Introduction. Ed. 8th, USA: Pearson Prentice Hall. 